\title{
Commercial catches and discards of a Mediterranean small-scale cuttlefish fishery: implications of the new EU discard policy
}

\author{
Maria del Mar Gil 1,2, Gaetano Catanese ${ }^{1,3}$, Miquel Palmer ${ }^{2}$, Hilmar Hinz ${ }^{2}$, Elena Pastor ${ }^{1}$, \\ Antoni Mira ${ }^{4}$, Amalia Grau ${ }^{1,3}$, Elka Koleva ${ }^{2}$, Antoni Maria Grau ${ }^{4}$, Beatriz Morales-Nin ${ }^{2}$ \\ ${ }^{1}$ Laboratori d'Investigacions Marines i Aqüicultura (LIMIA), Balearic Government, C/ Eng. Gabriel Roca 69, \\ 07157 Port d'Andratx, Balearic Islands, Spain. \\ (MMG) (Corresponding author) E-mail: mmgil@ dgpesca.caib.es. ORCID-iD: https://orcid.org/0000-0002-1044-0312 \\ (GC) E-mail: gcatanese@dgpesca.caib.es. ORCID-iD: https://orcid.org/0000-0001-6219-4494 \\ (EP) E-mail: epastor@dgpesca.caib.es. ORCID-iD: https://orcid.org/0000-0002-0130-2575 \\ (AG) E-mail: amaliagrau@dgpesca.caib.es. ORCID-iD: https://orcid.org/0000-0002-6461-6985 \\ ${ }^{2}$ Instituto Mediterráneo de Estudios Avanzados (IMEDEA), CSIC-UIB, C/ Miquel Marquès 21, 07190 Esporles, \\ Balearic Islands, Spain. \\ (MP) E-mail: palmer@imedea.uib-csic.es. ORCID-iD: https://orcid.org/0000-0002-7875-3673 \\ (HH) E-mail: hhinz@imedea.uib-csic.es. ORCID-iD: https://orcid.org/0000-0003-4909-0089 \\ (EK) E-mail: elka@imedea.uib-csic.es. ORCID-iD: https://orcid.org/0000-0002-9055-1070 \\ (BM-N) E-mail: beatriz@imedea.uib-csic.es. ORCID-iD: https://orcid.org/0000-0002-7264-0918 \\ ${ }^{3}$ INAGEA (INIA-CAIB-UIB), Carr. de Valldemossa, km 7.5, 07122 Palma, Balearic Islands, Spain. \\ ${ }^{4}$ Direcció General de Pesca i Medi Marí (DGPMM), Balearic Government, C/ Foners 10, 07006 Palma, \\ Balearic Islands, Spain. \\ (AM) E-mail: amira@dgpesca.caib.es. ORCID-iD: https://orcid.org/0000-0001-6018-0857 \\ (AMG) E-mail: agrau@dgpesca.caib.es. ORCID-iD: https://orcid.org/0000-0002-2633-6886
}

\begin{abstract}
Summary: The cuttlefish (Sepia officinalis) trammel net fishery is one of the most important small-scale fisheries in the Mediterranean Sea. Here we describe the main catch, by-catch and discard patterns found in this fishery on Mallorca Island by onboard surveys of 1005 netting walls from 23 fishing trips. The number of items captured, their size and their subsequent use, i.e. kept for sale or discarded, were recorded. Furthermore, the immediate survival of the unwanted items (i.e. vitality state when the gear came on board) and the medium-term survival of a subsample were assessed. The cuttlefish was the dominant species in the commercial fraction of the catch, particularly during the fishing season peak (March). However, S. officinalis catches quickly decreased further into the season, with other high-value fish, such as Scorpaena scrofa, increasing in the commercial fraction of the catch. As species composition is continuously changing, it is often difficult to determine the main target species of this fishery. This strategy possibly complicates management but maximizes fishing revenue, which was an average of $€ 175$ per trip. With respect to discards, up to 104 different species were caught but not commercialized. The most abundant were Holothuria sp. and Torpedo marmorata. Their immediate survival was $100 \%$ and $20 \%$, respectively. In both cases, the medium-term survival and the vitality status were high after seven days in monitored captivity. Therefore, in these cases, their immediate release to the sea should be promoted, given that they are exempt from the EU landing obligation. Interviews with fishers revealed that the perceived quantity of discards was lower than the amount recorded by the present study. Currently, just a small percentage $(1.5 \%)$ of these discards will be affected by the landing obligation enforced by the new European discards ban.
\end{abstract}

Keywords: small-scale fishery; trammel net; cuttlefish; discards; survival; Mallorca; western Mediterranean; fishers' perception; landing obligation.

Capturas comerciales y descartes de la pesquería artesanal de sepia en el Mediterráneo: implicaciones de la nueva política de descarte de la UE

Resumen: La pesquería de sepia (Sepia officinalis) con trasmallo es una de las pesquerías artesanales más importantes en el Mediterráneo. En este estudio describimos los principales patrones representados por esta pesquería en la isla de Mallorca a través de la inspección a bordo de 1005 paneles de red durante 23 jornadas de pesca. Se registró la cantidad de individuos capturados, su tamaño y su uso posterior, es decir, si se guardaron para su venta o se descartaron. Además, se evaluó la supervivencia inmediata (es decir, el estado de vitalidad cuando la red llegó a bordo) de los individuos no deseados y la supervivencia a medio plazo de una submuestra. La sepia fue la especie dominante en la fracción comercial de la captura, principalmente durante el pico de la temporada de pesca (marzo). Sin embargo, las capturas de $S$. officinalis disminuyeron rápidamente a lo largo de la temporada, mientras que otros peces de alto valor, como Scorpaena scrofa, aumentaron sus capturas. Como la composición de las especies cambia continuamente, a menudo es difícil discriminar las principales especies objetivo de esta pesquería. Esta estrategia posiblemente complica la gestión, pero maximiza los ingresos de los pescadores, que en promedio 
fueron de 175 Euros por jornada de pesca. En lo que respecta a los descartes, se capturaron 104 especies diferentes. Las más abundantes fueron Holothuria sp. y Torpedo marmorata. Su supervivencia inmediata fue del $100 \%$ y $20 \%$, respectivamente. En ambos casos, la supervivencia a medio plazo y el estado de vitalidad fueron altos después de 7 días en cautividad. Por lo tanto, en estos casos, se debía promover la liberación inmediata al mar, dado que estas especies están exentas de la obligación de desembarque de la UE. Las entrevistas a los pescadores revelaron que la cantidad percibida de descartes fue menor que las cantidades registradas en el presente estudio. Realmente, solo un pequeño porcentaje (1.5\%) de estos descartes se verá afectado por la obligación de desembarque impuesta por la nueva prohibición de descartes en Europa.

Palabras clave: pesquería artesanal; trasmallo; sepia; descartes; supervivencia; Mallorca; Mediterráneo occidental; percepción de los pescadores; obligación de desembarque.

Citation/Cómo citar este artículo: Gil M.M., Catanese G., Palmer M., Hinz H., Pastor E., Mira A., Grau A., Koleva E., Grau A.M., Morales-Nin B. 2018. Commercial catches and discards of a Mediterranean small-scale cuttlefish fishery: implications of the new EU discard policy. Sci. Mar. 82S1: 155-164. https://doi.org/10.3989/scimar.04735.03B

Editor: M. Demestre.

Received: November 29, 2017. Accepted: July 26, 2018. Published: October 10, 2018.

Copyright: ( 92018 CSIC. This is an open-access article distributed under the terms of the Creative Commons Attribution 4.0 International (CC BY 4.0) License.

\section{INTRODUCTION}

Small-scale fisheries are characterized by the use of small boats (less than $15 \mathrm{~m}$ long) and by being highly heterogeneous in terms of landings, fishing gear, fishing strategies and species targeted (Stergiou et al. 2006, Palmer et al. 2017). At the global scale, the importance of small-scale fisheries is based on the fact that they contribute half of the fish consumed by humans (FAO 2003, Stergiou et al. 2006). Small-scale fisheries predominate in developing countries, but they are also important in coastal areas of developed countries (Maynou et al. 2013).

In the Mediterranean, small-scale fleets play an important socio-economic role and have a longstanding tradition (Stergiou et al. 2006, MoralesNin et al. 2010). These fleets represent 80\% (42000 boats) of the EU Mediterranean fishing vessels and contribute $12 \%$ of the EU catches (C.O.M. 2002, Morales-Nin et al. 2010, Maynou et al. 2013). Mediterranean small-scale fisheries provide approximately 42800 jobs and represent $60.4 \%$ of the EU Mediterranean fishing sector employment (STECF 2017). The small-scale fisheries in the Balearic Islands (GSA05) provide fresh, local seafood of high quality to both local consumers and tourists (Morales-Nin et al. 2013, Quetglas et al. 2016). This fleet comprises 318 boats, which represent $85 \%$ of the total Balearic fleet (official data in 2016 from the Regional Fisheries Administration (Direcció General de Pesca i Medi Marí, DGPMM). The main métiers (i.e. the fishing gear targeting a specific group of species in a fishing area during a specific season) use static nets (trammel net and gillnet), mainly targeting spiny lobster, cuttlefish and red mullet, but small seines targeting dolphinfish or transparent goby and small longlines are also commonly used métiers (Quetglas et al. 2016, Palmer et al. 2017). The cuttlefish trammel net fishery comprises 93 boats (29\% of the small-scale fleet of the Balearic Islands), but this fishery is the most important in terms of fishing effort, with an average of 4964 fishing trips per year for the period 2004$2015(33.9 \%)$, and in terms of landings, with an average of 123 t/year (29.1\%; Palmer et al. 2017). The gross revenues of the cuttlefish fishery are $€ 959000$ per year (24.6\%), surpassed only by the spiny lobster trammel net fishery (Palmer et al. 2017).

Small-scale fisheries are generally considered datapoor in comparison with large-scale fisheries (Stergiou et al. 2006). In Mallorca, some data regarding target species of the cuttlefish fishery are available indicating that Sepia officinalis, whose catches (around $34000 \mathrm{~kg}$ / year) peak in early spring, may be near the maximum sustainable yield (Merino et al. 2008, Reglero and Morales-Nin 2008, Quetglas et al. 2015). However, the small-scale fisheries generally catch a substantial amount of non-target species (by-catch) that may be sold with relatively low market prices as mixed categories (Gil et al. 2018) or returned to the sea as discards. Discards constitute a substantial waste of natural resources that negatively affect the sustainable exploitation of marine ecosystems and the financial viability of fisheries (Kelleher 2005, Viana et al. 2013), though they can indirectly benefit some scavenging species, such as seabirds (Heath et al. 2014). Therefore, the European Commission has proposed a new plan to enforce the reduction of discards (Regulation EU No $1380 / 2013$ of the European Parliament and the Council on the Common Fisheries Policy). A landing obligation included in this new plan (Article 15 of EU Reg. 1380/2013) affects all commercial species subject to catch limits or minimum landing sizes with the aim of incentivizing the use of more selective gears and fishing practices (Salomon 2009, Veiga et al. 2016).

In general, the discard ratio in small-scale fisheries is less than $10 \%$ to $15 \%$ (Borges et al. 2001, Tsagarakis et al. 2014), so it tends to be lower than in most industrial fisheries (Bellido et al. 2011). However, for European waters in particular, the discard ratio of small-scale fisheries is highly variable and dependent on a number of factors such as métier, market influence and fishing practices (Veiga et al. 2016). Furthermore, the impact of discarding at the ecosystem level ultimately depends on survival probability, which is highly variable and species-specific. Unfortunately, proper estimation of survival is complicated, but even crude estimates could be used to propose precautionary exceptions to the landing obligation. 
Here we use the cuttlefish trammel net fishery on Mallorca as a representative case study for most smallscale fisheries. Though specific data on the target species may be available, more comprehensive knowledge at the overall métier level is needed, not only to improve the assessment and management of small-scale fisheries but also to determine how the new discard European policy is perceived by the fishers. Thus, a multi-purpose survey was conducted with the aim of updating the knowledge gaps in four specific areas: (1) assessing the seasonal variation on all the marketed catch in order to determine the relative importance of by-catch in relation to the nominal target species; (2) describing the discards composition in terms of number of items and weight; (3) estimating the immediate and the medium-term survival probability of discards and (4) rating the fishers' perception of discards and of the new EU discards ban.

\section{MATERIALS AND METHODS}

\section{Description of the local fishery}

The cuttlefish trammel net fishery operates in Mallorca from January to July, with a clear spring (March and May) peak in catches (Quetglas et al. 2015). The cuttlefish trammel nets are generally deployed at shallow depths of approximately 10 to $30 \mathrm{~m}$, just at the lower boundary of the seagrass (Posidonia oceanica) meadows (Palmer et al. 2017).

The fishery is locally regulated by the Balearic Government (Regulation of Artisanal Fisheries in Balearic Inland Waters, Decree 17/2003, Balearic Official Gazette 28, 01/03/2003). Trammel nets used in this fishery have a total maximum length restriction of $2000 \mathrm{~m}$ per crew member (up to a maximum cumulative length of $5000 \mathrm{~m}$ ). Because of the size of the local boats and crew, fishers in Mallorca usually fish with nets of approximately $1000 \mathrm{~m}$ length. Each trammel net is composed of 20 netting walls, each of which is approximately $50 \mathrm{~m}$ long. The mesh has a minimum legal size of $67 \mathrm{~mm}$ in the inner panel, although fishers often use nets with a mesh size of $80 \mathrm{~mm}$, which corresponds to the minimum legal size allowed in the Balearic marine protected areas.

\section{Sampling}

A total of 23 fishing trips was surveyed along Mallorcan coasts in the period February to July from 2015 to 2017. Sampling was conducted on two commercial boats, each rigged with two sets of trammel nets (Table 1), fishing at depths ranging from 10 to $32 \mathrm{~m}$ (mean \pm sd: $17.9 \pm 4.5 \mathrm{~m})$.

For each fishing trip, the date, name of the boat, location, weather and sea conditions and depth were recorded by an observer on board. Also, for each trammel net, the initial and end coordinates and the number of netting walls were noted. As the net was progressively retrieved on board the boat, most of the items caught, either commercial or discard species, were assigned to a specific netting wall and were immediately identified to
Table 1. - Summary of number of fishing trips, trammel nets and netting walls surveyed on Mallorca Island, 2015-2017.

\begin{tabular}{lccc}
\hline Boat & Num. trips & Num. trammel nets & Num. netting walls \\
\hline$\# 1$ & 11 & 22 & 470 \\
$\# 2$ & 12 & 24 & 535 \\
Total & 23 & 46 & 1005 \\
\hline
\end{tabular}

the lowest taxonomic level possible (usually to species level). Moreover, they were measured with a ruler, or if that was not possible, they were assigned by eye into ten-centimetre-increment size classes. Finally, the status of the discarded captures was determined before they were returned to the sea, based on their vitality (i.e. the individuals without reflexes or movement were considered dead, and otherwise they were considered alive). These data were used to estimate the immediate survival, detecting the probability of survival at the moment when the gear arrived on board. A subsample of live animals was retained on board and transported for the assessment of medium-term survival (detailed below).

Small animals, such as small invertebrates, and fragments of sessile organisms, such as Posidonia oceanica leaves and stems, were continuously falling from the net onto the deck. This fraction of the catch, which is part of the discard, could not be assigned to a specific netting wall, so was instead assigned at the trammel net level. All these organisms were collected separately for each trammel net and were kept for further analysis. In the laboratory, all organisms were identified to the species level when possible and weighed.

All data collected, both on board and in the laboratory, were organized into a hierarchical (fishing trip, trammel net, netting wall, item) database.

\section{Survival experiments}

A subsample of animals that were to be discarded but that were alive when they came on board was used to assess medium-term survival. These animals were transferred to an onboard tank with sea water and continuous aeration and were transported to the Marine Research and Aquaculture Laboratory (LIMIA) of the Balearic Government, Spain, at the end of the fishing journey. The selected species were those with high abundance and an immediate survival higher than $20 \%$.

The collected species were maintained separately in tanks according to the size of the individual, with continuous seawater overflow and controlled temperature. The status of the tested specimens was determined using a vitality scale (Benoît et al. 2010): 1, excellent; 2, good; 3, poor; and 4, moribund. The status of the specimens was recorded on their arrival (Day 0) and after seven days in the laboratory. The survival of each specimen was checked daily.

\section{Interviews with fishers}

A questionnaire was designed to investigate the fishers' perception about the new European discards ban. The questionnaire was designed for face-to-face interviews in the native language of the interviewee. The interview process started with the interviewee 
signing a confidentiality form, followed by the interviewer providing a short verbal description of the objectives of the project and a project brochure (available at http://minouw-project.eu/resources). Several questions, some of them open ended, were asked:

- What is the proportion of discards in the capture $(0 \%-10 \%, 10 \%-25 \%, 25 \%-50 \%, 50 \%-75 \%$ or $75 \%-100 \%)$ ?

- What are the most frequently discarded species (open question)?

- What percentage of discards corresponds to captures affected by the landing obligation (open question)?

- Will the application of the landing obligation affect the cost of the activity, the sorting time or the needs of personnel (Yes or No)?

Seven professional fishers who usually work in the trammel net cuttlefish fishery in different Mallorcan ports were interviewed. This fraction of interviewed fishers corresponded to $14 \%$ of fishers working in the cuttlefish fishery on Mallorca Island in 2016 (official data from the Regional Fisheries Administration (Direcció General de Pesca i Medi Marí, DGPMM). The interviews were conducted from November 2015 to January 2016.

\section{Data analysis}

\section{Representativeness of the sampled boats}

Data from other small-scale fisheries strongly suggest that between-boat variability is smaller than the temporal (seasonal) variability within a given boat (Catanese et al. 2018). Therefore, considering the logistic constraints of sampling on commercially operating boats, only two boats were surveyed in this study. However, the marketed captures of these sampled boats were compared with the marketed captures of the rest of the cuttlefish trammel net fleet.

The daily captures are sorted by fishermen in standard boxes that are sold in a daily auction that takes place at the Palma Fishing Wharf (Reglero and Morales-Nin 2008). During the auction, the assigned commercial category and the weight $(\mathrm{kg})$ and sale price $(€ / \mathrm{kg})$ of each box are recorded for the entire Mallorcan fleet. These data are transferred daily to the Mediterranean Institute for Advanced Studies (IMEDEA, CSIC-UIB), where the identities of the fishers are encrypted in accordance with the terms of a confidentiality agreement. The records corresponding to the cuttlefish trammel net fishery during the period 2015-2017 were filtered using the algorithm described in Palmer et al. (2017). These data were reorganized into a matrix by pooling all the landings of a given boat in a given day. The matrix was submitted to a principal components analysis (PCA) that was completed using the rda function of the vegan library (Oksanen et al. 2014) of the R package (at http://www.r-project.org/) on Hellinger-transformed data (Borcard et al. 2011) using the decostand function of the vegan library. The similarity patterns in landings at the between-boat and within-boat level were depicted using a plot of the scores on the first two dimensions of the PCA space.

\section{Characterization of captures}

The abundance of all the species captured during the sampling was compared in terms of both number of items and weight $(\mathrm{g})$. Two separate analyses (commercial and discarded species) were completed. The fraction of discards of fragments of sessile organisms such as Posidonia oceanica, algae or Porifera was not considered in the comparison of the number of items because of their uncountable nature. However, this fraction was included in the weight comparison.

The weight of the individuals sampled on board was obtained using length-weight relationships (Morey et al. 2003, İlkyaz et al. 2008, Bilge et al. 2014). However, when no length measure was available for a given item, the average length of all the conspecific items was used.

\section{Monthly changes in commercial captures and profit}

The temporal trends of catches of cuttlefish (i.e. the nominal target species) during the sampling period (February to July) were compared with the catches of the rest of commercialized captures pooled together (i.e. commercialized by-catch). The cumulated weight of target captures and commercialized by-catch per month was standardized using the total number of surveyed trips (i.e. taking into account the number of netting walls deployed on each trip) sampled in a given month.

The gross revenues of these two fractions were estimated from the first sale price at the central wharf in Mallorca. In order to avoid any market fluctuation, the average daily price of a given commercial category was calculated from all the fish of this category sold in a given day. The revenue corresponding to a given fishing trip was estimated after multiplying the weight of all the commercialized items recorded onboard by the average daily price of the corresponding commercial category. Note that in some cases a single species can be sold as several commercial categories (i.e. based on size). In those cases, the average price of all possible commercial categories was considered.

\section{RESULTS}

\section{Representativeness of the sampled boats}

After compiling the data from all the fishing trips of all the boats of the cuttlefish trammel net fleet, the seasonal variation in landing composition (i.e., biomass of the different commercial categories) was found to be larger than the between-boat variation: the convex polygon including all the fishing trips of each of the two sampled boats (dashed polygons in Fig. 1) included the average scores of all the boats in the fleet (i.e. averaged landing composition of any given boat; points in Fig. 1). Accordingly, in spite of the small number of surveyed boats $(4 \%$ of the boats that used cuttlefish trammel nets at least once during the study period), the data should be considered representative of the métier activity. 


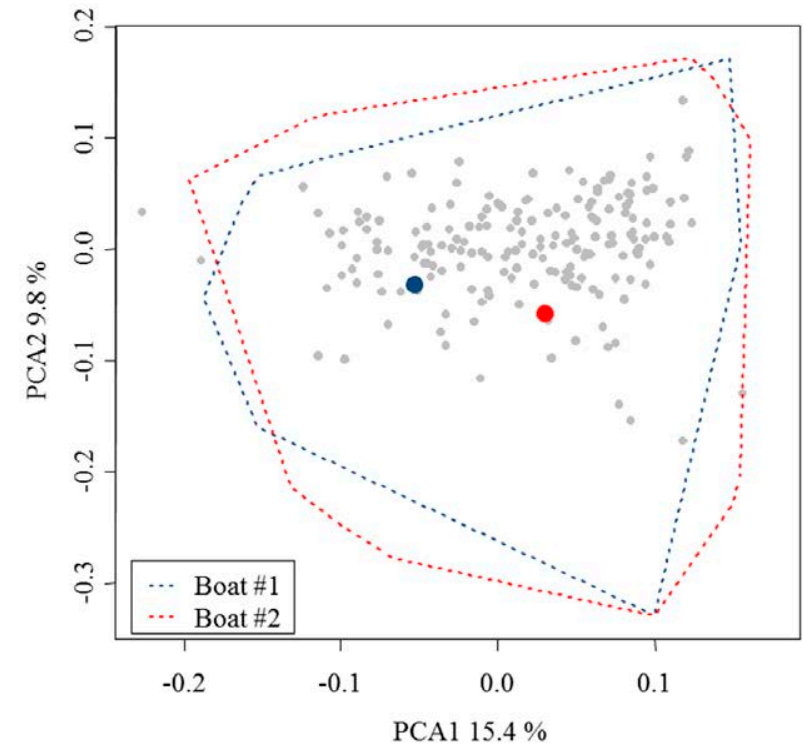

Fig. 1. - PCA plot of landed commercial captures ( $\mathrm{kg}$ of each commercial category) for all the (daily) fishing trips of the cuttlefish trammel net fleet from Mallorca during the period 2015-2017. The grey points denote the average scores for all the boats (i.e. centroid) and the larger, coloured points denote the sampled boats. For these two boats, the envelope polygon including all the fishing trips of each boat is also indicated.

\section{Assessment of commercial captures}

A total of 1224 individuals captured and retained for sale were surveyed during this study, corresponding to a total of 46 different species. The most frequently commercialized species was the target species, Sepia officinalis, with an abundance of 0.35 items and $173.35 \mathrm{~g}$ per netting wall (Fig. 2). The second most

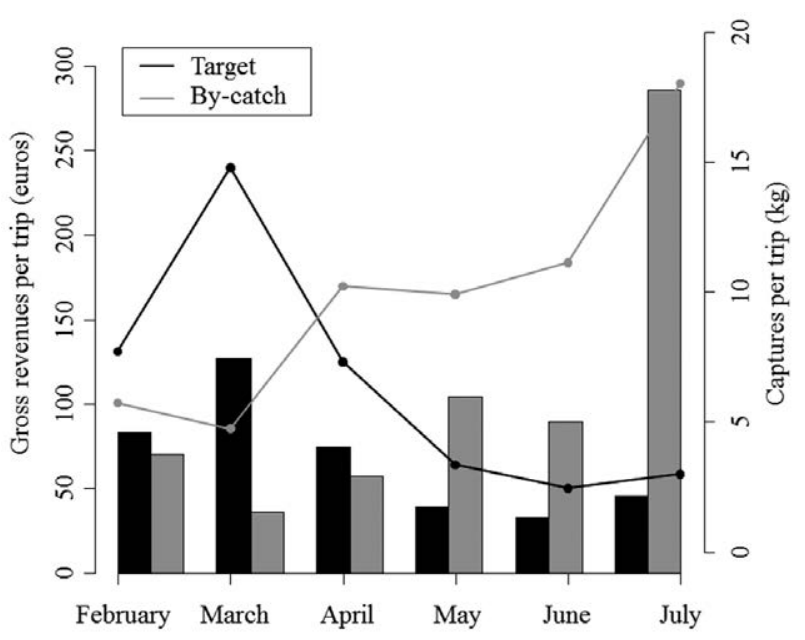

Fig. 3. - Monthly variation of captures ( $\mathrm{kg}$ ) per trip (lines) of targeted and untargeted commercial captures and gross revenues in euros (bars) obtained from the sale of these captures.

common commercial capture was Scorpaena porcus (0.15 items per netting wall), followed by the gastropods Hexaplex trunculus, Stramonita haemastoma and Bolinus brandaris (Fig. 2A). However, due to their small size, these gastropods had little importance in the weight comparison. The high-value species Scorpaena scrofa, Zeus faber and Dentex dentex were relatively abundant, with a weight of $66.90,8.28$ and 7.55 g per netting wall, respectively (Fig. 2B).

The monthly temporal trends of commercial captures of the target species were compared with the trends of the rest of the commercialized species pooled together (i.e. commercialized by-catch; Fig. 3). The captures of the target species peaked in March with an abundance of $14.79 \mathrm{~kg}$ per trip but decreased sharply
A

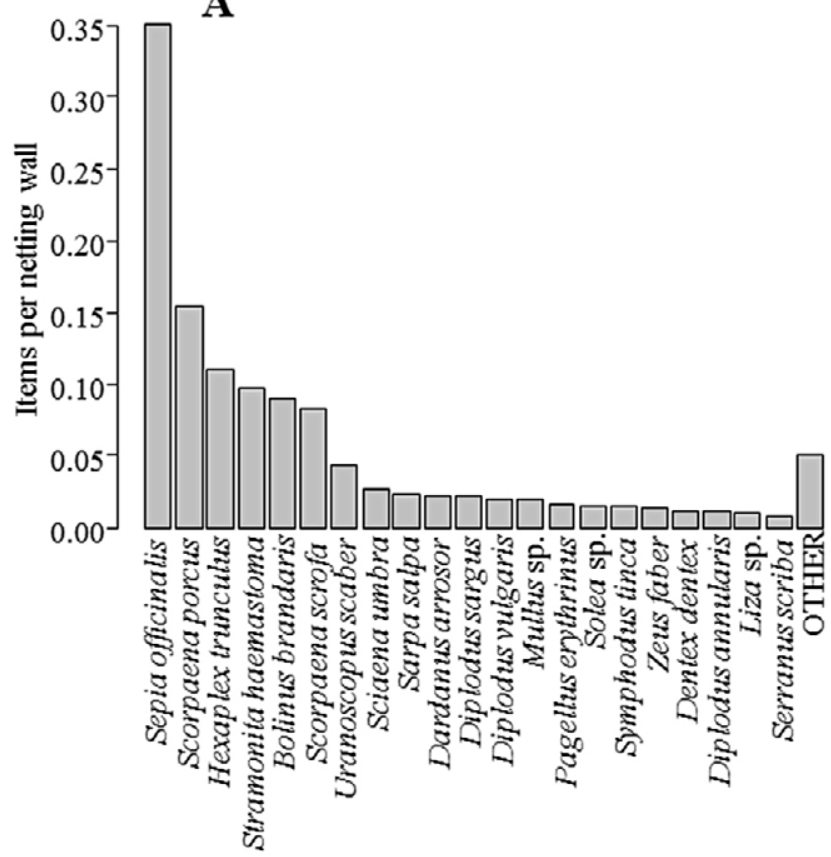

B

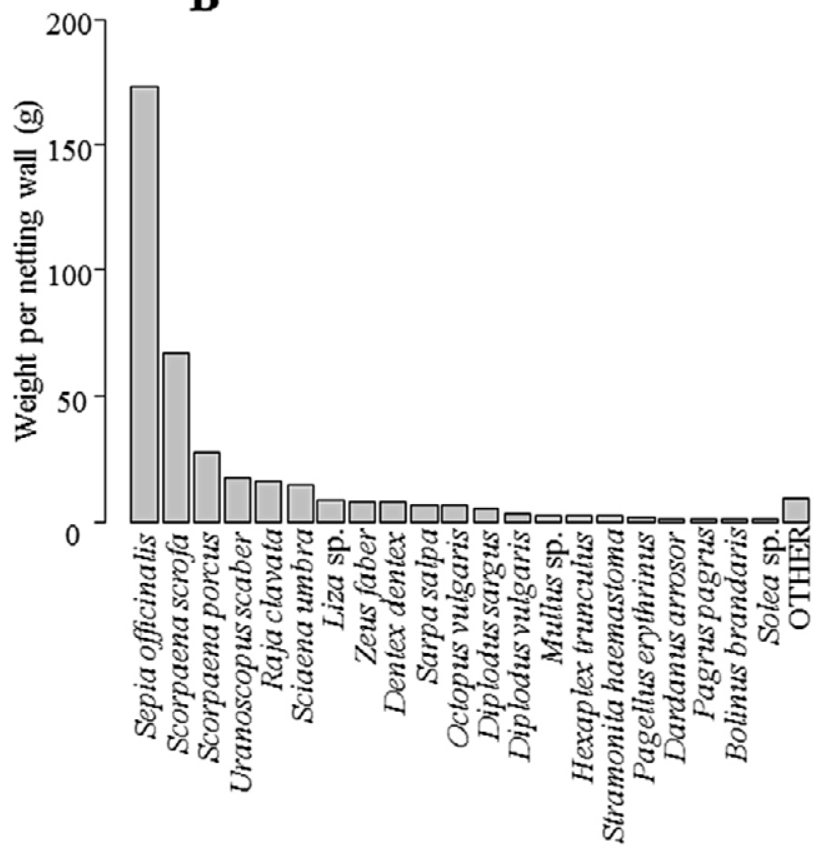

Fig. 2. - Abundance and biomass of commercial species in the surveyed trammel nets estimated as number of items per netting wall (A) and weight (in g) per netting wall (B). 

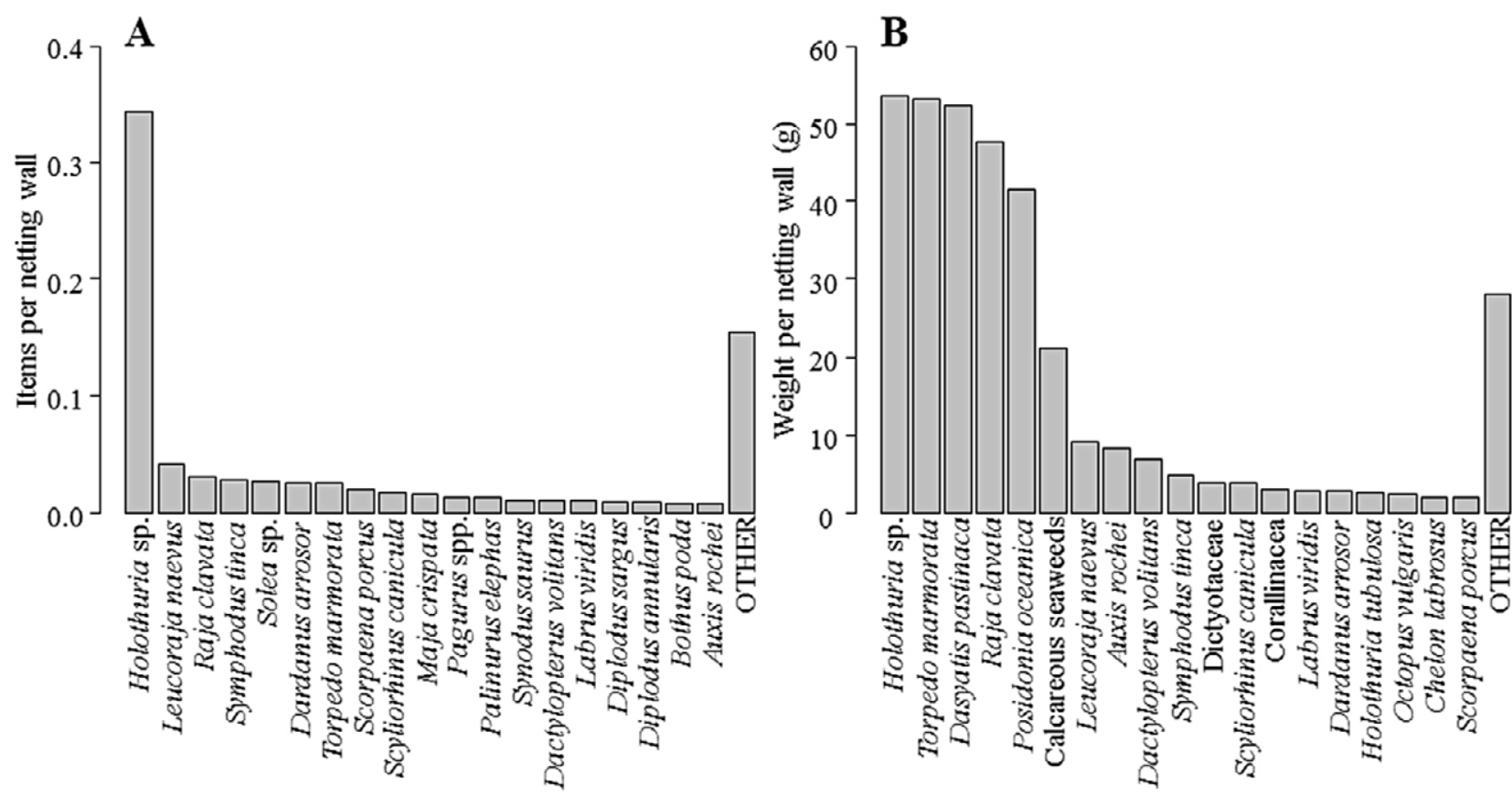

Fig. 4. - Abundance of discarded species in the surveyed trammel nets estimated as number of items per netting wall (A) and weight (in g) per netting wall (B).

as the fishing season progressed. Conversely, the capture of the commercialized by-catch increased as the fishing season progressed, with a maximum weight of captures observed in July (18.02 kg per trip). Similarly, the gross revenues, estimated as the weight captured multiplied by the average price, followed the same pattern. The gross revenues of the target species were higher in March (€127.17 per trip) but then decreased with the decline of captures. However, the gross revenues of the commercialized by-catch were higher at the end of the fishing season, reaching values in July that were even higher than those of the target species in March (€286.08 per trip). After combining all the data (i.e. target and by-catch species), the mean revenues throughout the season were $€ 174.82$ per trip (95\% confidence interval: $€ 123.48-311.24)$.

\section{Characterization of discards}

A total of 825 discarded captures (i.e. items captured and discarded) was surveyed during this study, distributed across a total of 95 different species. The most discarded species was Holothuria sp. (Fig. 4A), with an abundance of 0.34 items per netting wall. This group includes the species Holothuria tubulosa and Holothuria forskåli, which are abundant in the coastal zone of the Mediterranean but are difficult to differentiate due to a lack of external diagnostic features. The rest of the discards were low-value species such as Leucoraja naevus and Raja clavata, small-sized species and damaged items that otherwise might have a higher price. The group OTHER, which encompasses all the discarded species with fewer than eight specimens, cannot be neglected ( 0.15 items per netting wall), indicating that a large number of different species are captured in very low numbers. The analysis of the weight of discards captured (Fig. 4B) was markedly different from the analysis of the number of items. Although Holothuria sp. was still the most abundant species (53.6 g per netting wall), in this case some species that were captured at a lower frequency but with a high weight showed similar values (e.g. Torpedo marmorata, Dasyatis pastinaca or Raja clavata). Furthermore, fragments of sessile organisms, such as Posidonia oceanica and calcareous seaweeds (mainly composed of Lithothamnion spp.), represented a nonnegligible fraction of the discards (41.6 and $21.2 \mathrm{~g}$ per netting wall, respectively).

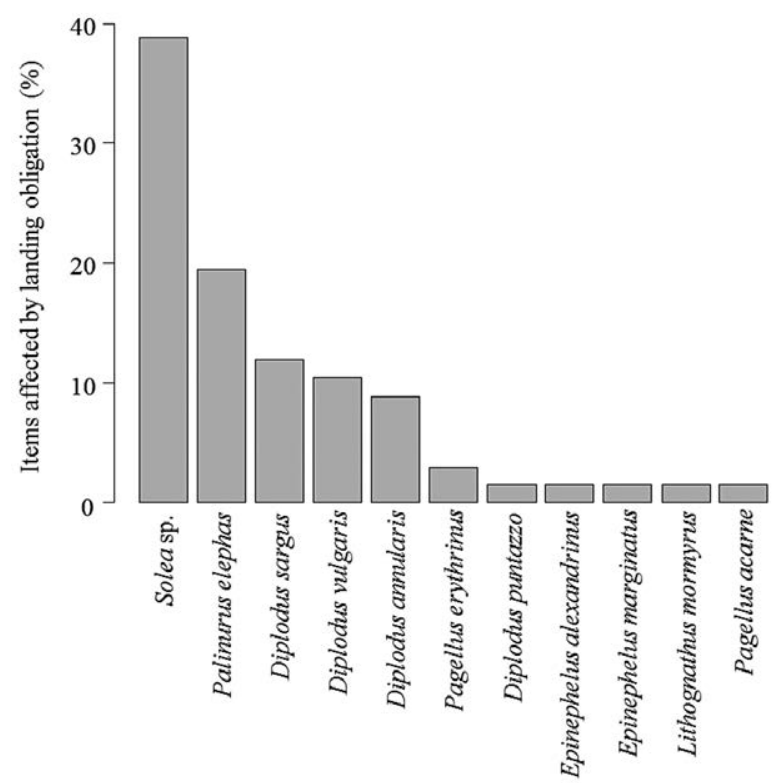

Fig. 5. - Percentage of abundance of the 67 discarded captures affected by the landing obligation (Article 15 of EU Reg. 1380/2013) in the 1005 netting wall surveyed in this study. 
Up to $47.7 \%$ of the catch in terms of weight was discarded; however, this percentage was reduced to $42.0 \%$ when the fragments of the aforementioned sessile organisms were not considered. Similarly, the discarded percentage in terms of number of items was $40.3 \%$.

In the cuttlefish trammel net fishery in Mallorca, only the species for which there exists a European minimum legal size (Annex III to Regulation EC No 1967/2006) will be affected by the landing obligation of the new European discards ban. Just 67 of the 825 discarded items (i.e. 8.1\%) were captured under their minimum legal size (Fig. 5). These captures corresponded to $1.5 \%$ of the total discarded weight.

\section{Survival of discards}

To determine immediate survival, 729 non-commercialized individuals of 62 species were examined when the net came on board, and 456 were found alive. The immediate survival of the 18 most frequent discarded species $(n>8)$ is shown in Figure 6. Invertebrate species, such as Holothuria sp., Palinurus elephas, Maja crispata and Dardanus arrosor, had a high survival rate, close to $100 \%$. However, fish species showed lower immediate survival, ranging from $62 \%$ for Scorpaena porcus to $5.4 \%$ for Raja clavata. Conversely, Synodus saurus, Labrus viridis, Dactylopterus volitans and Auxis rochei showed $100 \%$ mortality when the net came on board.

The immediate survival of the 67 discarded items affected by the landing obligation was analysed separately. However, some of them were captured in a very low number, so only the most frequent species $(n>8)$ were considered for the immediate survival estimation. The probability of immediate survival of Palinurus elephas was $100 \%$, while that of Solea sp. was $62 \%(95 \%$ Bayesian credibility interval between 0.42 and 0.79 ).

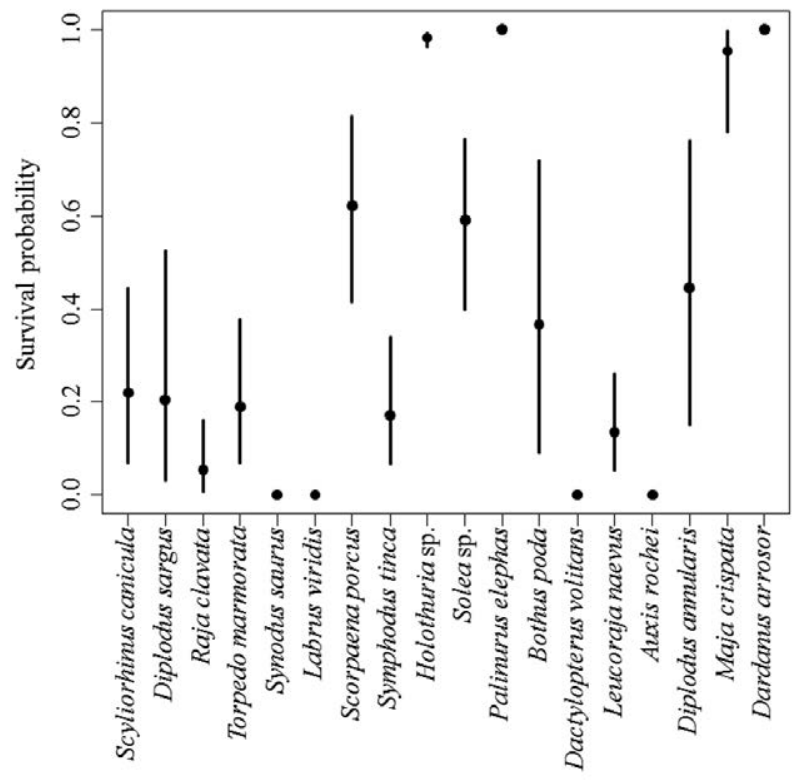

Fig. 6. - Probability of immediate survival (at the moment the gear came on board) of the most discarded species $(n>8)$. The dispersion bar corresponds to $95 \%$ Bayesian credibility intervals of survival probability.
Table 2. - Delayed survival of some discarded species after seven days in captivity conditions. Mean values of the initial (Day 0) and final (Day 7) vitalities for the Benoît et al. (2010) scale are indicated (1, excellent; 2, good; 3 , poor; and 4, moribund).

\begin{tabular}{lccc}
\hline \multicolumn{1}{c}{ Species } & $\begin{array}{c}\text { No. tested } \\
\text { individuals }\end{array}$ & Initial vitality Final vitality \\
\hline Holothuria sp. & 7 & 3.0 & 1.0 \\
Dardanus arrosor & 3 & 2.0 & 1.0 \\
Torpedo marmorata & 2 & 2.5 & 1.0 \\
Scyliorhinus canicula & 2 & 1.5 & 1.0 \\
\hline
\end{tabular}

To determine medium-term survival, a total of 14 specimens of 4 different species (Holothuria sp., Dardanus arrosor, Torpedo marmorata and Scyliorhinus canicula) were transported to the laboratory in order to estimate the delayed survival (Table 2). All the specimens survived after 7 days in captivity. The initial vitality state (Day 0) ranged between 1.5 and 2.86. However, the final vitality state (Day 7) was 1 in all cases, which corresponds to an excellent condition.

\section{Fishers' interviews}

The fishers' perception of the discarded captures and the fishers' opinion of the expected outcomes of the new landing obligation measures were recorded by means of seven face-to-face interviews. Four of the interviewed fishers believed that the discard ratio for the cuttlefish trammel net fishery was between $0 \%$ and $10 \%$. The other three fishers believed that it was between $10 \%$ and $25 \%$. According to fishers' perceptions, the most frequently discarded species were Holothuria sp., Dardanus sp. (i.e. Dardanus arrosor and Dardanus calidus), Torpedo marmorata, Scorpaena porcus, Dasyatis pastinaca, Dactylopterus volitans and specimens of the Asteroidea family.

According to the fishers' perceptions, the percentage of discards affected by the landing obligation was very small (mean \pm sd: $4.3 \pm 6.7 \%$ ). Finally, most $(85.7 \%)$ of the interviewed fishers reported that the application of the landing obligation will not increase the costs of the activity, the sorting time or the needs of onboard personnel.

\section{DISCUSSION}

The cuttlefish trammel net fishery in Mallorca Island is representative of many other similar smallscale fisheries in the sense that in spite of its high socio-economic and cultural importance (Merino et al. 2008, Palmer et al. 2017), almost all of the data available are related to the target species. Here we demonstrate the usefulness of a multi-purpose observer survey to close knowledge gaps that ultimately may improve fisheries management under the new EU discard regulation.

\section{Commercial catches}

The most abundant commercial capture was the nominal target species, Sepia officinalis, with 0.35 items per netting wall, but a long list of untargeted species was also marketed (up to 45 different spe- 
cies), suggesting a low selectivity of this gear and supporting the importance of the by-catch in this fishery and probably in most of the Mediterranean small-scale fisheries (Palmer et al. 2017). The revenues corresponding to such an apparently untargeted fraction became higher than the revenues of the target species as the fishing season progressed, thus supporting its great importance for total revenues (Batista et al. 2009). Accordingly, fishers may be progressively changing their fishing tactics using essentially the same net and fishing grounds to maximize profits. These changes are largely driven by external constraints such as cuttlefish catchability, catchability of by-catch and market demand. It appears that while fishers and managers continue to label the métier as cuttlefish trammel net, the fishers' intentions are to maximize not the weight of cuttlefish catches but rather the total revenues. Most fishers are at or near the economic sustainability level (Maynou et al. 2013), so proper assessment and management of the fisheries should take into account that fishing tactics may be continuously adapted from mainly targeting cuttlefish to mainly targeting some of the by-catch species. In some studies, trammel nets deployed around the lower limit of $P$. oceanica are split into two different métiers based on a given threshold of catch similarity (Quetglas et al. 2016). However, a pragmatic alternative, which may better reflect fishers' intentions, would be to consider them a single métier (cuttlefish/fish) because even fishers themselves are not able to accurately discriminate between them (Palmer et al. 2017).

During the fishing season, the captures of the target species peaked in March and April and decreased afterwards. The captures of commercialized by-catch showed the opposite trend, and captures increased from March and April onwards. The most plausible explanation for such a pattern is that the catchability or abundance of cuttlefish and by-catch change during the fishing season. The cuttlefish peak may be related to an increased catchability associated with the seasonal spawning migrations (Boletzky 1983, Belcari et al. 2002). Therefore, cuttlefish are available to the cuttlefish trammel net fishery from the end of winter (Boletzky 1983), while from autumn to winter the cuttlefish retreat to deeper waters, where they are mostly exploited by trawlers (Belcari et al. 2002, Keller et al. 2014). Conversely, the commercialized bycatch is mainly composed of demersal species that, in most cases, exhibit a home range behaviour. Therefore, the increase in catchability may not be related to migration but to increased activity, which may be ultimately driven by a water temperature increase. The positive relationship between catchability with passive gear and water temperature has been proposed elsewhere (Villegas-Ríos et al. 2014). In fact, the increased activity during the warmer seasons is related to intensified feeding to recover from the previous spawning effort in winter or to store energy for the next reproductive season, representing an increase in the probability of encounter between fish and fishers (Villegas-Ríos et al. 2014).

\section{Discards}

In this study, the discard ratio in weight (47\%) was higher than those reported for similar trammel nets: about $10 \%$ in the Patraikos Gulf (Tzanatos et al. 2007) and $22 \%$ on the Portuguese coast (Batista et al. 2009). Conversely, the discard ratio in number of items reported here $(40 \%)$ was smaller than in other studies. For example, discard ratios of $53 \%$ and $49 \%$ were respectively reported by Batista et al. (2009) and Gonçalves et al. (2007). In this study, the most frequently discarded item by far was Holothuria sp., which represented $15.2 \%$ of the discarded captures in weight and $41.8 \%$ in number of items. However, some large specimens of elasmobranchs such as Torpedo marmorata, Dasyatis pastinaca and Raja clavata had great importance for the total discarded weight, although they were captured in low numbers. Some of these elasmobranch species were also frequently discarded captures in the cuttlefish trammel net fishery on the coast of Sicily (Tiralongo et al. 2018).

Immediate return to the sea of the species showing high post-release survival is recommended, but proper assessment of survival is very difficult. Specifically, keeping animals in captivity is confounding the effects on survival of captivity itself with the effects of fishing (Pollock and Pine 2007). Nevertheless, the results on immediate and medium-term survival reported here may justify at least precautionary advice. For example, immediate survival for Holothuria sp. was $98 \%$ and medium-term survival was $100 \%$. Therefore, the immediate return to the sea is recommended for this species because nearly $100 \%$ of captured specimens will survive and will be not affected by the fishing practice. Torpedo marmorata and Scyliorhinus canicula showed lower immediate survival (around 20\%) but excellent medium-term survival, so returning them to the sea is also recommended. Releasing practices will be banned under the EU landing obligation for some species according to the new European discards regulation; however, none of these species (i.e. Holothuria sp., Torpedo marmorata and Scyliorhinus canicula) are affected by the new enforcement (Landing obligation, Article 15 of Regulation EU 1380/2013).

Live shoots, stems and rhizomes of the protected species Posidonia oceanica are a non-negligible part of the discards, indicating that the fishing gear interacted with this habitat-forming species. Therefore, the relative importance of effects of the trammel nets on seagrass meadows in relation to other potential impacts requires immediate attention.

The fishers' perception of discards agreed well with the results reported here in terms of species composition. In contrast, their perceived quantity of discards was lower than the actual amount reported here. As in other cases, it seems that the accuracy of past experiences is biased by memory and subjectivity (Bradburn et al. 1987, Hassan 2005, Damalas et al. 2015). Therefore, studies based on interviews should not attempt to obtain quantitative estimates, though they may be extremely useful for knowing and understanding the general perceptions of the fishers. More interestingly, 
the landing obligation is not viewed as a threat, but this point is discussed in depth in the next section.

\section{Implications of the new European discard regulation}

The new orientation of the Common Fisheries Policy (EU Regulation 1380/2013) calls for moving towards a gradual elimination of discards on a case-bycase basis. The landing obligation has been included in this new plan with the aim of encouraging fishers to use more selective fishing gear and practices (Salomon 2009, Veiga et al. 2016). However, only those species subject to catch limits or minimum landing sizes will be affected by the landing obligation in the Mediterranean. In this study, only 67 items $(1.5 \%$ of discarded weight) would be affected by the landing obligation. This result agrees with the opinion of the interviewed fishers, who reported a low percentage of discards affected by the landing obligation, and most of them $(86 \%)$ believe that the application of the landing obligation will not have any negative effects on their fishing activities. Note, however, that this fishers' perception may change depending on the fishery. For example, fishers from a small-scale Galician gillnet fishery, which targets some species managed by total allowable catches, perceived that the landing obligation will negatively impact on their household economies (Villasante et al. 2016).

According to Article 15 of EU Regulation $1380 / 2013$, some exemptions from the landing obligation are allowed:

A) Catches of prohibited species, which must be returned to the sea. In this study, no species prohibited in the Balearic Islands (Decree 139/2011 and Order AAA/1771/2015) were captured.

B) Catches of those species for which there is scientific evidence of high post-release survival rates. The two most abundant species affected by the landing obligation (Solea sp. and Palinurus elephas) could have a high probability of surviving. Notably, undersized Palinurus elephas, which showed $100 \%$ immediate survival in this study, showed an almost complete recovery of their vitality status a few days after fishing (Catanese et al. 2018).

C) Specific de minimis values of up to $5 \%$ of total catches of all species subject to the landing obligation under certain conditions. However, this exemption seems to have been developed for target species of industrial or large-scale fisheries.

Contrasting with the limited outcomes of exceptions, it is noteworthy that in the case of the cuttlefish fishery and other small-scale fisheries in Mallorca, a large amount of the catch is sold as mixed-fish commercial categories which may be biasing the landings statistics (Gil et al. 2018). This mixing strategy is fully in accordance with EU policy, which is intended to reduce discards by marketing lower-valued specimens (Gil et al. 2018).

In summary, here we demonstrate that assessing and managing small-scale fisheries based on the target species only provides a potentially biased view. In the case of Mallorca Island's cuttlefish trammel net fishery, by-catch has even greater economic importance than the target species, the discarded fraction cannot be ignored, the survival probability of such a discarded fraction must be properly assessed and fisher's perceptions should be accounted for. However, more effort should be invested in the future not only to estimate the relative impact of small-scale fishing at the ecosystem level, but also in other potential drivers affecting the long-term ecosystem dynamics, which should be based on long-term, comprehensive monitoring.

\section{ACKNOWLEDGEMENTS}

This study is a result of the Associated Unit LIMIA-IMEDEA. It received funding from the European Commission's Horizon 2020 Research and Innovation Programme under Grant Agreement No. 634495 for the Science, Technology, and Society Initiative to Minimize Unwanted Catches in European Fisheries (MINOUW). G. Catanese was supported by a postdoctoral research contract from INIA-CCAA. H. Hinz was supported by a Ramón y Cajal Fellowship (grant funded by the Ministerio de Economía y Competitividad de España and the Conselleria d'Educació, Cultura i Universitats de la Comunidad Autónoma de las Islas Baleares). The authors would like to thank all cuttlefish trammel net fishers who collaborated in the interviews and the onboard surveys.

\section{REFERENCES}

Batista M.I., Teixeira C.M., Cabral H.N. 2009. Catches of target species and bycatches of an artisanal fishery: The case study of a trammel net fishery in the Portuguese coast. Fish. Res. 100: 167-177. https://doi.org/10.1016/j.fishres.2009.07.007

Belcari P., Sartor P., Sanchez P., et al. 2002. Exploitation patterns of the cuttlefish, Sepia officinalis (Cephalopoda, Sepiidae), in the Mediterranean Sea. Bull. Mar. Sci. 71: 187-196.

Bellido J.M., Santos M.B., Pennino M.G., et al. 2011. Fishery discards and bycatch: solutions for an ecosystem approach to fisheries management? Hydrobiologia 670: 317-333. https://doi.org/10.1007/s10750-011-0721-5

Benoît H.P., Hurlbut T., Chassé J. 2010. Assessing the factors influencing discard mortality of demersal fishes using a semi-quantitative indicator of survival potential. Fish. Res. 106: 436-447. https://doi.org/10.1016/j.fishres.2010.09.018

Bilge G., Yapıcı S., Filiz H., et al. 2014. Weight-length relations for 103 fish species from the southern Aegean Sea, Turkey. Acta Ichthyol. Piscat. 44: 263-269. https://doi.org/10.3750/aip2014.44.3.11

Boletzky S.V. 1983. Sepia officinalis. In: Boyle P.R. (ed.), Cephalopod Life Cycles, vol. I. Academic Press, pp. 31-52.

Borcard D., Gillet F., Legendre P. 2011. Numerical Ecology with R. Springer New York, USA, 306 pp. https://doi.org/10.1007/978-1-4419-7976-6

Borges T.C., Erzini K., Bentes L., et al. 2001. By-catch and discarding practices in five Algarve (southern Portugal) métiers. J. Appl. Ichthyol. 17: 104-114. https://doi.org/10.1111/j.1439-0426.2001.00283.x

Bradburn N.M., Rips L.J., Shevell S.K. 1987. Answering autobiographical questions: the impact of memory and inference on surveys. Science 236: 157-161. https://doi.org/10.1126/science.3563494

COM. 2002. Communication from the Commission to the Council and the European Parliament laying down a Community Action Plan for the conservation and sustainable exploitation of fishery resources in the Mediterranean Sea under the Common Fisheries. Commission of the European Communities, Brussels, 37 pp. 
Catanese G., Hinz H., Gil M.M., et al. 2018. Comparing the catch composition, profitability and discard survival from different trammel net designs targeting common spiny lobster (Palinurus elephas) in a Mediterranean fishery. PeerJ 6: e4707. https://doi.org/10.7717/peerj.4707

Damalas D., Maravelias C.D., Osio G.C., et al. 2015. Historical discarding in Mediterranean fisheries: a fishers' perception. ICES J. Mar. Sci. 72: 2600-2608. https://doi.org/10.1093/icesjms/fsv141

FAO. 2003. Strategies for increasing the sustainable contribution of small-scale fisheries to food security and poverty alleviation. In: Report of the twenty-fifth session of the Committee on Fisheries. FAO, Italy, pp. 76-84.

Gil M.M., Palmer M., Rosselló R., et al. 2018. Mixed-fish commercial categories as a strategy for reducing discards from the small-scale fleet. Fish. Res. 205: 105-114. https://doi.org/10.1016/j.fishres.2018.04.011

Gonçalves J.M.S., Stergiou K.I., Hernando J.A., et al. 2007. Discards from experimental trammel nets in southern European small-scale fisheries. Fish. Res. 88: 5-14 https://doi.org/10.1016/j.fishres.2007.06.017

Hassan E. 2005. Recall bias can be a threat to retrospective and prospective research designs. Internet J. Epidemiol. 3: 1-7.

Heath M.R., Cook R.M., Cameron A.I., et al. 2014. Cascading ecological effects of eliminating fishery discards. Nature Comm. 5: 3893. https://doi.org/10.1038/ncomms4893

İlkyaz A.T., Metin G., Soykan O., et al. 2008. Length-weight relationship of 62 fish species from the Central Aegean Sea, Turkey. J. Appl. Ichthyol. 24: 699-702. https://doi.org/10.1111/j.1439-0426.2008.01167.x

Kelleher K. 2005. Discards in the world's marine fisheries. An update. FAO, Italy, $131 \mathrm{pp}$.

Keller S., Valls M., Hidalgo M., et al. 2014. Influence of environmental parameters on the life-history and population dynamics of cuttlefish Sepia officinalis in the western Mediterranean. Estuar. Coast. Shelf Sci. 145: 31-40. https://doi.org/10.1016/j.ecss.2014.04.016

Maynou F., Morales-Nin B., Cabanellas-Reboredo M., et al. 2013. Small-scale fishery in the Balearic Islands (W Mediterranean): A socio-economic approach. Fish. Res. 139: 11-17. https://doi.org/10.1016/j.fishres.2012.11.006

Merino G., Morales-Nin B., Maynou F., et al. 2008. Assessment and bioeconomic analysis of the Majorca (NW Mediterranean) trammel net fishery. Aquat. Living Resour. 21: 99-107. https://doi.org/10.1051/alr:2008027

Morales-Nin B., Grau A.M., Palmer M. 2010. Managing coastal zone fisheries: A Mediterranean case study. Ocean Coast. Manage. 53: 99-106. https://doi.org/10.1016/i.ocecoaman.2010.01.003

Morales-Nin B., Cardona-Pons F., Grau A.M., et al. 2013. Does angling activity influence consumer choices of fresh fish? Br. Food J. 115: 1054-1066. https://doi.org/10.1108/BFJ-04-2011-0096

Morey G., Moranta J., Massutí E., et al. 2003. Weight-length relationships of littoral to lower slope fishes from the western Mediterranean. Fish. Res. 62: 89-96. https://doi.org/10.1016/S0165-7836(02)00250-3

Oksanen J., Blanchet F.G., Kindt R., et al. 2014. Vegan: Community Ecology Package. $\mathrm{R}$ package version 2.2-0.

Palmer M., Tolosa B., Grau A.M., et al. 2017. Combining sale records of landings and fishers knowledge for predicting métiers in a small-scale, multi-gear, multispecies fishery. Fish. Res. 195: 59-70.

https://doi.org/10.1016/j.fishres.2017.07.001

Pollock K.H., Pine W.E. 2007. The design and analysis of field studies to estimate catch-and-release mortality. Fish. Manage. Ecol. 14: 123-130. https://doi.org/10.1111/j.1365-2400.2007.00532.x

Quetglas A., Keller S., Massutí E. 2015. Can Mediterranean cephalopod stocks be managed at MSY by 2020? The Balearic Islands as a case study. Fish. Manage. Ecol. 22: 349-358. https://doi.org/10.1111/fme.12131

Quetglas A., Merino G., Ordines F., et al. 2016. Assessment and management of western Mediterranean small-scale fisheries. Ocean Coast. Manage. 133: 95-104. http://doi.org/10.1016/j.ocecoaman.2016.09.013

Reglero P., Morales-Nin B. 2008. Relationship between first sale price, body size and total catch of trammelnet target species in Majorca (NW Mediterranean). Fish. Res. 92: 102-106. https://doi.org/10.1016/j.fishres.2008.01.010

Salomon M. 2009. Recent European initiatives in marine protection policy: towards lasting protection for Europe's seas? Environ. Sci. Policy 12: 359-366. https://doi.org/10.1016/j.envsci.2008.12.008

Scientific, Technical and Economic Committee for Fisheries (STECF). 2017. The 2017 Annual Economic Report on the EU Fishing Fleet (STECF-17-12). Publications Office of the European Union.

Stergiou K.I., Moutopoulos D.K., Soriguer M.C., et al. 2006. Trammel net catch species composition, catch rates and métiers in southern European waters: A multivariate approach. Fish. Res. 79: $170-182$. https://doi.org/10.1016/j.fishres.2006.03.003

Tiralongo F., Messina G., Lombardo B.M. 2018. Discards of elasmobranchs in a trammel net fishery targeting cuttlefish, Sepia officinalis Linnaeus, 1758, along the coast of Sicily (central Mediterranean Sea). Reg. Stu. Mar. Sci. 20: 60-63. https://doi.org/10.1016/j.rsma.2018.04.002

Tsagarakis K., Palialexis A., Vassilopoulou V. 2014. Mediterranean fishery discards: review of the existing knowledge. ICES J. Mar. Sci. 71: 1219-1234. https://doi.org/10.1093/icesjms/fst074

Tzanatos E., Somarakis S., Tserpes G., et al. 2007. Discarding practices in a Mediterranean small-scale fishing fleet (Patraikos Gulf, Greece). Fish. Manage. Ecol. 14: 277-285. https://doi.org/10.1111/j.1365-2400.2007.00556.x

Veiga P., Pita C., Rangel M., et al. 2016. The EU landing obligation and European small-scale fisheries: What are the odds for success? Mar. Policy 64: 64-71. https://doi.org/10.1016/j.marpol.2015.11.008

Viana M., McNally L., Graham N., et al. 2013. Ignoring discards biases the assessment of fisheries' ecological fingerprint. Biol. Lett. 9: 20130812. https://doi.org/10.1098/rsbl.2013.0812

Villasante S., Pierce G.J., Pita C., et al. 2016. Fishers' perceptions about the EU discards policy and its economic impact on smallscale fisheries in Galicia (North West Spain). Ecol. Econ. 130: 130-138. https://doi.org/10.1016/j.ecolecon.2016.05.008

Villegas-Ríos D., Alós J., Palmer M., et al. 2014. Life-history and activity shape catchability in a sedentary fish. Mar. Ecol. Progr. Ser. 515: 239-250. https://doi.org/10.3354/meps 11018 